\title{
Development of a Gas Chamber for Detecting Broiler Chicken Halothane Sensitivity and PSE (Pale, Soft, Exudative) Meat Formation
}

\author{
Denis Fabrício Marchi ${ }^{1}$, Alexandre Oba $^{2}$, Iris Lamberti Ziober ${ }^{1}$, Adriana Lourenço \\ Soares ${ }^{1}$, Elza Iouko Ida ${ }^{1}$ and Massami Shimokomaki ${ }^{1 *}$ \\ ${ }^{I}$ Departamento de Ciência e Tecnologia de Alimentos; Universidade Estadual de Londrina; Londrina - PR - Brasil. \\ ${ }^{2}$ Departamento de Ciência Animal; Centro de Ciências Agrárias; Universidade Estadual de Londrina; C.P.: 6001; \\ 86051-970; Londrina - PR - Brasil
}

\begin{abstract}
The objective of this work was to investigate the use of a halothane to screen broiler chickens prone to develop PSE (Pale, Soft, Exudative) meat through a special gas chamber connected to a veterinarian anaesthetic apparatus developed in our laboratory. Anaesthesia was induced with approx. $3.0 \%$ halothane at a flow rate of $6.0 \mathrm{Lm}^{-1}$ in pure oxygen for 5 min. Commercial male broilers $(n=342)$ aged 46 days old were evaluated and classified as either halothane sensitive (HAL+) or insensitive (HAL-), depending on the leg rigidity response. Approximately $27.5 \%$ $(n=94)$ of broilers were HAL+ and $72.5 \%(n=248)$ were HAL-. This is a simple and rapid technique to evaluate broiler sensitivity to halothane and identify broilers prone to develop PSE meat. The occurrence of PSE meat in HAL insensitive broiler chicken samples suggests that other factors are related to PSE occurrence.
\end{abstract}

Key words: Halothane test, colour, $\mathrm{pH}$

\section{INTRODUCTION}

Broiler breast meat colour abnormalities, such as PSE (Pale, Soft, Exudative) meat, have been subject of studies by our research group in an attempt to find their possible causes and thus develop methodologies to avoid, or at least reduce, the occurrence of PSE meat. Abnormal meat colour, from yellowish (PSE) to excessive red (DFD-like, dark, firm, and dry) may be unacceptable to consumers and inappropriate for meat processing. Our rough estimate is that, in
2003, the Brazilian meat companies' annual production loss due to PSE meat was around US $\$ 10$ million (Oda et al., 2003). Because of the growth of the broiler chicken production, this loss may rise to US $\$ 30$ million in 2008. Findings by our group have revealed that supplementing birds' diets with vitamin $\mathrm{E}$ can decrease PSE meat (Olivo et al., 2001) and increased phospholipase A2 activity (Soares et al., 2003) enhances lipid oxidation in PSE meat (Soares et. al. 2009). Showering the birds before slaughtering at the commercial processing plant calms the birds

*Author for correspondence: mshimo@uel.br 
down, contributing to re-establish $\mathrm{Ca}^{2+}$ homeostasis (Guarnieri et al., 2004). Transportation conditions from the farm to the commercial abattoir can also influence the formation of PSE meat (Simões et al., 2009). An ultrastructural study revealed a shortage of robust sarcomeres within the muscle fibrils (Guarnieri et al., 2004). There is growing evidence that bird exposure to thermal stress conditions just before slaughter is another cause of PSE meat (Barbut, 1998, Shimokomaki and Olivo 2006, Simões et al., 2009). Obviously, PSE meat results from multifactorial agents and the main causes are yet to be elucidated. Intense genetic selection aiming at producing fast weight-gaining birds might result in abnormal muscle biochemical behaviour (Anthony, 1998). In swine, the main cause of PSE meat is already known (Fujii et al., 1991). It has been found to be associated to skeletal muscle disturbance, which may lead to death under animal exposure to stressful heat conditions or halothane anaesthesia (Malignant Hyperthermia), resulting in Pork Stress Syndrome - PSS. The biological linkage of this condition is the halothane gene (hal) or ryanodine receptor gene (ryrl). Ryanodine controls $\mathrm{Ca}^{2+}$ flow in muscle excitation-contraction coupling at the sarcoplasmic reticulum and is responsible for the acceleration of muscle metabolism when the DNA mutation occurs. This alteration causes pork PSE formation (Mickelson and Louis, 1996). The gene hal is then related to halothane sensitivity: normal pigs are dominant $(\mathrm{NN})$, sensitive pigs are recessive $(\mathrm{nn})$, and there are the hybrid ones $(\mathrm{Nn})$. This discovery allowed establishing a genetic pig selection methodology, which is currently commercially available. Recently Oda et al. (2009) observed that the $\beta$-RYR genic expression that leads to broiler PSE meat is in relatively lower concentration than in normal birds, suggesting a broiler PSE genetic origin similar to that of pork PSE.

The present work describes the development of a gas chamber to detect broiler sensitivity under halothane anaesthesia for screening and identifying birds prone to develop PSE meat.

\section{MATERIALS AND METHODS}

\begin{abstract}
Animals
Male commercial broilers ( $\mathrm{n}=342)$ aged 46 days raised at the Londrina State University (UEL) farm were submitted to halothane testing using the developed experimental apparatus. Food and water were withdrawn $1.0 \mathrm{~h}$ and $10.0 \mathrm{~h}$ before sacrificing, respectively. The slaughtering of the commercial birds was carried out at UEL farm and consisted essentially of electrical stunning, bleeding, defeathering, evisceration, carcass water cooling, deboning, and chilling (Northcutt, 2001, Guarnieri et al., 2004). The carcasses were refrigerated at $4{ }^{\circ} \mathrm{C}$ for $24 \mathrm{~h}$.
\end{abstract}

\section{Halothane testing}

Our especially lab-made experimental anaesthetic chamber $(12 \times 12 \times 100-\mathrm{cm})$ can test three birds at a time accommodated in the three chamber holes. An outside top exhaust is connected to a veterinarian anaesthetic apparatus. Anaesthesia was induced with approx. $3.0 \%$ halothane in pure oxygen at a flow rate of $6.0 \mathrm{~L} \cdot \mathrm{min}^{-1}$. Figure 1 shows the apparatus. Anaesthesia was maintained for $5 \mathrm{~min}$ and the birds' reactions were monitored throughout the experiment. Unconscious birds were examined for leg muscle rigidity. If one or both legs were completely extended and rigid, the birds were classified as halothane sensitive (HAL+) (Fig. 2 b and c), while irresponsive birds were classified as halothane insensitive (HAL-) (Fig. 2 a). Twenty-five HAL+, HAL- birds were sacrificed to determine PSE meat characteristics.

\section{Determination of PSE meat characteristics}

PSE breast fillet meat was characterized by $\mathrm{pH}$ and colour evaluation by $\mathrm{L}^{*}$ values as described in Olivo et al. (2001). Briefly, $\mathrm{pH}$ was measured in a Testo $205 \mathrm{pH}$ meter by inserting an electrode into the breast muscle; a Minolta CR 400 colorimeter was used to evaluate the $\mathrm{L}^{*}$ value (CIELAB colour system) on the posterior surface of 24-h post-mortem intact skinless Pectoralis major. Samples whith $\mathrm{L}^{*}$ value $\geq 53.0$ and $\mathrm{pH}<5.9$ was classified as PSE meat, while sample whith L* value between 44.0 and 53.0 and $\mathrm{pH} \geq 5.9$ was classified as Normal meat. 


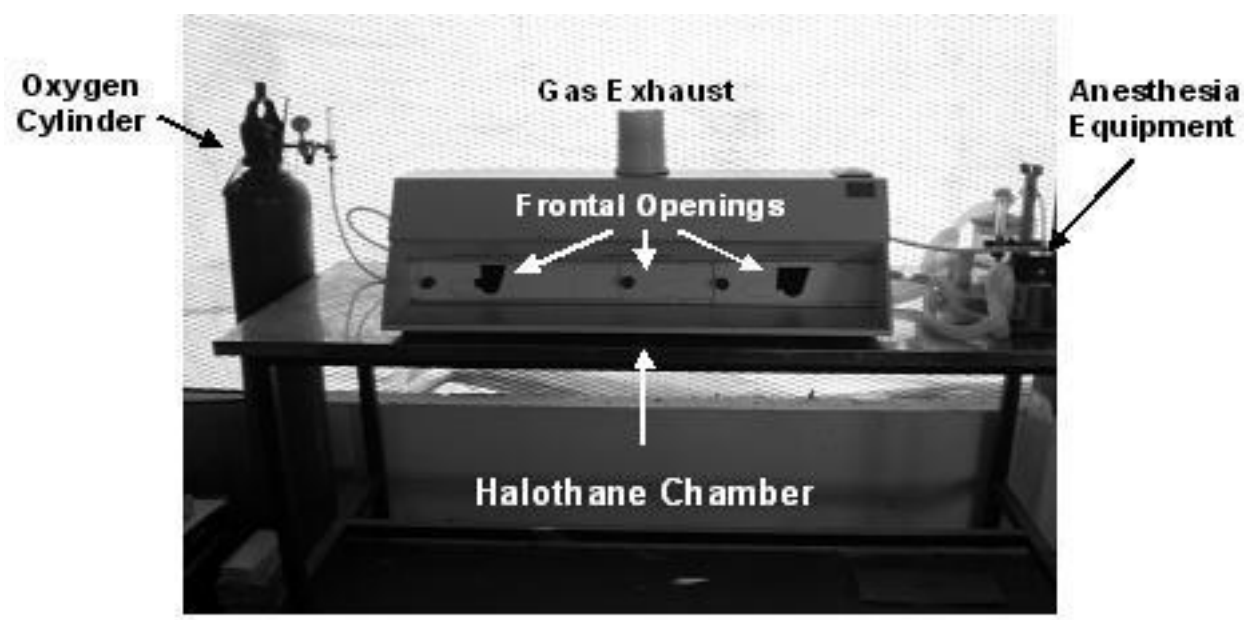

Figure 1 - Broiler halothane test chamber with anaesthesia equipment. Halothane gas concentration was set at $3.0 \%$ in pure oxygen. Three birds can be placed in the halothane chamber per experiment run.

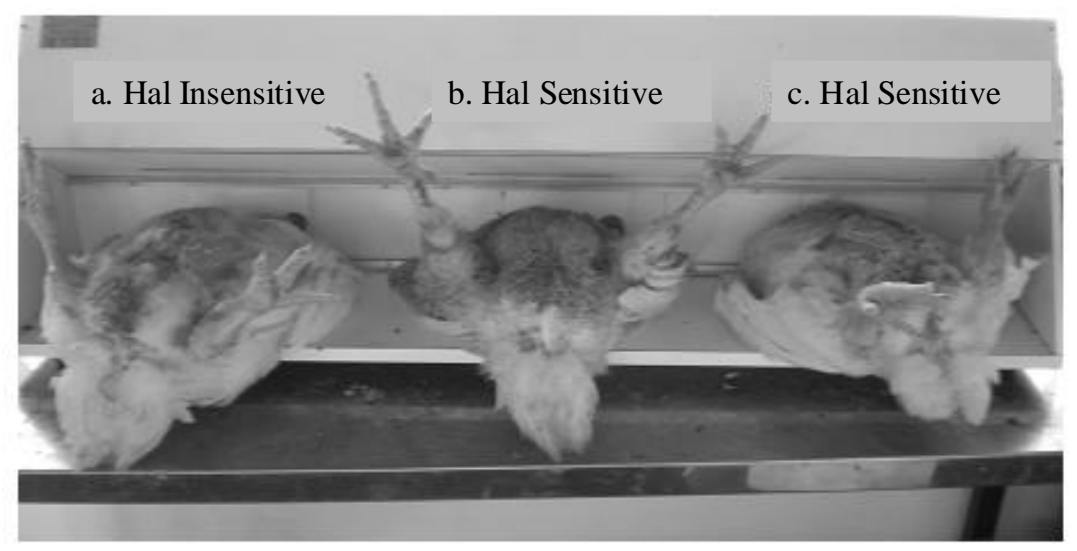

Figure 2 - Broiler leg rigidity sensitivity to $3.0 \%$ halothane gas: a) HAL- (Hal insensitive), b and c) HAL+ (Hal sensitive).

\section{RESULTS}

\section{Halothane tests}

The occurrence of positive and negative halothane sensitivity in the commercial broiler lineage studied is illustrated in Figure 3. From the 342 birds tested, $27.5 \%$ were sensitive to halothane and classified as $\mathrm{HAL}+, 72.5 \%$ were insensitive to halothane treatment and classified as HAL-.

\section{PSE meat occurrence}

The Figure 4 presents the occurrence of PSE meat in HAL + and HAL- broiler meat samples after the classification of breast meat by $\mathrm{pH}$ and $\mathrm{L}^{*}$ values. The results indicate occurrences of $40.0 \%$ PSE meat in HAL + broilers, while only $28.0 \%$ of HALbroilers presented PSE meat characteristics. In a commercial plant survey, a figure of $22.0 \%$ of PSE meat was reported by Soares et al., (2003). 


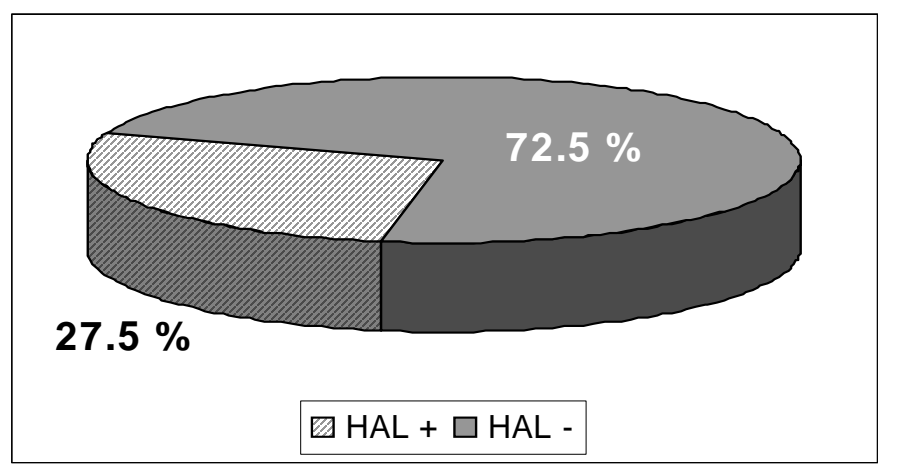

Figure 3 - Occurrence of broiler positive HAL+ and negative HAL - response to halothane test.

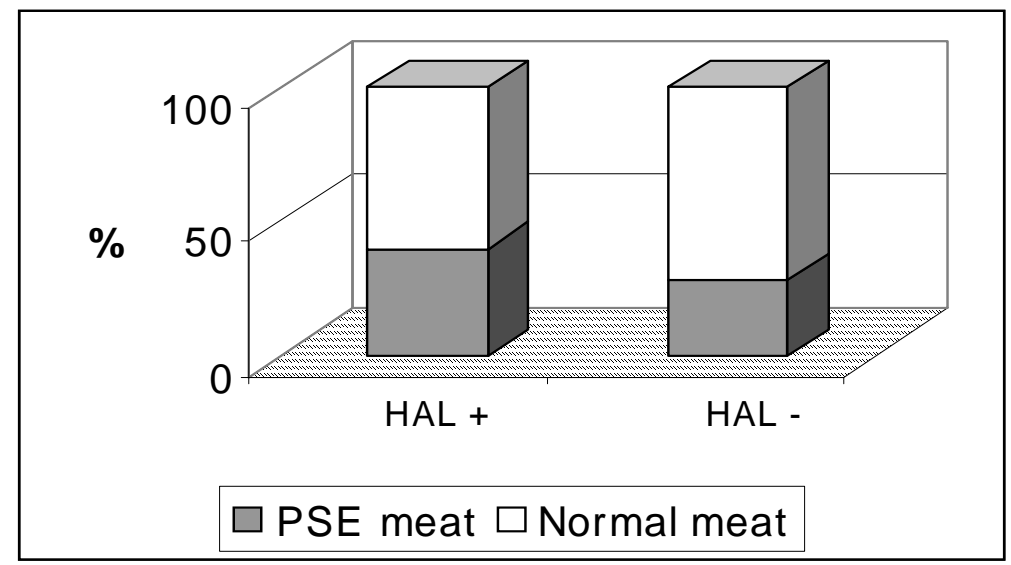

Figure 4 - Occurrence of PSE meat in halothane sensitive (HAL+) and insensitive birds (HAL-).

\section{DISCUSSION}

Other authors have reported results similar to those shown in Figure 3. Cavitt et al. (2004) found 13.2 to $22.9 \%$ halothane sensitivity in commercial broiler lineages and Owens et al. (2000) reported a halothane sensitivity variation from $3.5 \%$ to $10.0 \%$ in turkey, while Wheeler et al. (1999) obtained $5.0 \%$ halothane sensitivity, $85.0 \%$ halothane insensitivity, and $10.0 \%$ halothane intermediate response in turkey. To prove that poultry hal gene truly plays a role in the manifestation of PSE meat, it is necessary to determine the presence of the ryanodine genotype as routinely carried out in pig PSS (Fujii et al, 1991), which we are currently investigating (Oda et al., 2009). The total PSE meat characteristics for all HAL+ and HALsamples were $36.0 \%$ with $26.6 \%$ HAL+ and $9.4 \%$ HAL-. However, 9.4\% PSE meat for the halgroup indicates that the PSE meat origin is not due only to the ryanodine gene. Under these experimental conditions, it seems that preslaughtering management is a key factor in PSE meat formation. In fact, we recently observed that the lorry thermal microenvironment during broiler transportation, associated with the transportation distance, is a main factor to consider (Simões et al., 2009). Thus, the results reported herein clearly demonstrate that other non-hal factors determine the onset of PSE meat along with genetic origin, particularly pre-slaughter management factors that may be quantitatively as important as the hal gene. 


\section{CONCLUSION}

The anaesthetic halothane chamber screening developed at UEL is simple and rapid technique, which is an alternative for the identification of broiler chickens prone to the development of PSE meat. The occurrence of PSE meat in HAL insensitive broiler chicken samples suggests that other factors are related to PSE occurrence.

\section{ACKNOWLEDGMENTS}

This work was partially funded by Fundação Araucária/FINEP, Fundação Araucária/CNPq Pronex (Protocol \# 09.277). Thanks also go to CAPES Foundation for graduate scholarships to DFM and ILZ. EII and MS are CNPq Research Fellows.

\section{RESUMO}

O objetivo deste trabalho foi investigar o uso do halotano para avaliar e identificar frangos propensos ao desenvolvimento de carnes PSE (Pálida, Flácida, Exsudativa) por meio de uma câmara desenvolvida em nossos laboratórios. Esta foi conectada a um equipamento de anestesia veterinária e a anestesia foi então induzida com aproximadamente $3,0 \%$ de halotano a um fluxo de $6,0 \mathrm{~L} / \mathrm{min}$ em puro oxigênio. A sensibilidade de três frangos foi avaliada simultaneamente. Os frangos de linhagem comercial $(n=352)$ com 46 dias de idade foram expostos à $3,0 \%$ de halotano por 5 min e classificados como halotano sensível $(\mathrm{HAL}+)$ e não-sensível (HAL -), baseado no enrijecimento dos seus membros inferiores. Aproximadamente $27,5 \%(n=94)$ frangos foram HAL+ e 72,5\% (n=248) HAL-. Amostras do músculo Pectoralis major $(\mathrm{n}=75)$ foram coletadas após o abate dos animais para as medidas de $\mathrm{pH}$ e cor, determinadas nos filés mantidos a $4 \mathrm{C}$ por 24 h postmortem. Frangos HAL+ apresentaram maior porcentagem de carnes PSE quando comparadas ao grupo HAL-. Este é um teste simples e rápido para a avaliação da sensibilidade das aves ao halotano e identificar frangos propensos ao desenvolvimento de carnes PSE embora amostras de HAL - também apresentaram carnes PSE sugerindo que outros fatores estão relacionados com a formação da anormalidade.

\section{REFERENCES}

Anthony, N. B. (1998), Journal of Muscle Foods, 9, 2533.

Barbut, S. (1998), Estimating the magnitude of the PSE problem in poultry. Journal of Muscle Foods, 9, 3549.

Cavitt, L. C., Hargis, B. M. and Owens, C. M. (2004), The use of halothane and succinylcoline to identify broilers prone to developing pale, soft, exudative meat. Poultry Science, 83, 1440-1444.

Fujii, J., Otsu, K., Zorzato, F., Leon, S., Khanna, V. K., Weiler, J. E., O’Brien, P. J. and Macleinnan, D. H. (1991), Identification of mutation in porcine ryanodine receptor associated with malignant hyperthermia. Science, 253, 448-451.

Guarnieri, P. D., Soares, A. L., Olivo, R. Schneider, J. P., Macedo, R. M., Ida, E. I. and Shimokomaki, M. (2004), Preslaughter handling with water shower spray inhibits PSE (Pale, Soft, Exudative) broiler breast meat in a commercial plant. Journal of Food Biochemistry, 24, 269-277.

Mickelson, J. R. and Louis, C. F. (1996), Malignant hyperthermia: excitation-contraction coupling, $\mathrm{Ca}^{2+}$ regulation defects. Physiology Review, 76, 537-592.

Oda, S. H. I., Schneider, J., Soares, A. L., Barbosa, D. M. L., Ida, E. I., Olivo, R. and Shimokomaki, M. (2003), Detecção de cor em filés de peito de frango. Revista Nacional da Carne, 28, 30-34.

Northcutt, J. K. (2001), Preslaughter factors affecting poultry meat quality In Poultry Meat Processing (A. R. Sams, ed.) Boca Raton, pp 5-18.

Oda, S. H. I., Nepomuceno, A. L., Ledur, M. C., Oliveira, M. C. N., Marin, S. S. R., Ida. E. I. and Shimokomaki, M. (2009), Quantitative differential expression of alpha and beta ryanodine receptor genes in PSE (Pale, Soft, Exudative) meat from two chicken lines: broiler and layer. Brazilian Archives of Biology and Technology. In press

Olivo, R., Soares, A. L., Ida, E. I. and Shimokomaki, M. (2001), Dietary Vitamin E inhibits poultry PSE and improves meat function properties. Journal of Food Biochemistry, 25, 271-283.

Owens, C. M., Matthews, N. S. and Sams, A. R. (2000), The use of halothane gas to identify turkeys prone to developing pale, exudative meat when transported before slaughter. Poultry Science, 79, 789-795.

Shimokomaki, M. and Olivo, R. (2006), Carnes PSE em frangos. In Atualidades em Ciência e Tecnologia de Carnes, Shimokomaki et al., ed. Varela, São Paulo, p. 95-104.

Simões, G. S., Rossa, A., Oba, A., Matsuo, T., Shimokomaki, M., Ida, E. I. (2009), Transporte e Ocorrência de PSE (Pale, Soft, Exudative) E A-Dfd (Dark, Firm, Dry) em Filés de Peito de Frango durante o Inverno. Revista Nacional da Carne. In press. 
Soares, A., L., Ida, E. I., Miyamoto, S., Blazquez, F. J. H., Olivo, R., Pinheiro, J.W. and Shimokomaki, M. (2003), Phospholipase A2 activity in poultry PSE, Pale, Soft, Exudative. Journal of Food Biochemistry, 27, 309-319.

Soares, A. L., Marchi, D. F., Matsushita, M., Guarnieri, P. D., Droval, A., Ida, E. I. and Shimokomaki, M. Lipid oxidation and changes in fatty acids profile related to broiler breast meat colour abnormalities. Brazilian Archives of Biology and Technology In press.

Wheeler, B. R., Mckee, S.R., Matthews, N.S., Miller, R.K. and Sams, A. R. A. (1999), Poultry Science, 78, 1634-1638. 